MR. FERRAN ESTRADA (Orcid ID : 0000-0001-5536-0183)

Article type : Paper

\title{
Tectonic indentation in the central Alboran Sea (westernmost Mediterranean)
}

Ferran Estrada, ${ }^{1}$ Jesús Galindo-Zaldívar, ${ }^{2,3}$ Juan Tomás Vázquez, ${ }^{4}$ Gemma Ercilla, ${ }^{1}$ Elia D’Acremont, ${ }^{5}$ Belén Alonso ${ }^{1}$ and Christian Gorini ${ }^{5}$

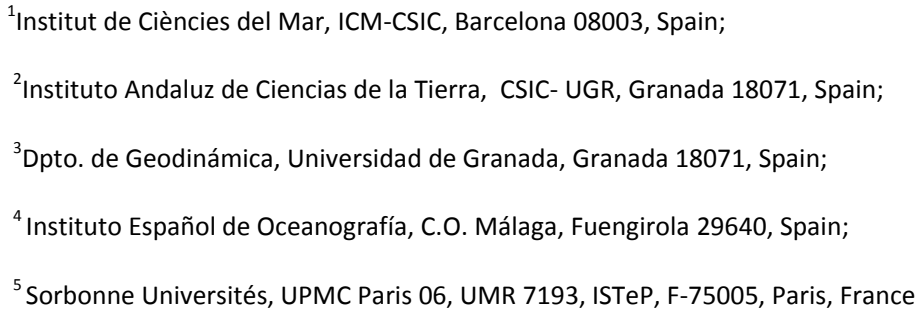

\section{Contact details:}

Ferran Estrada;

Telephone: +34932309601;

Fax: +34932309555

Email: festrada@icm.csic.es

Running title: Tectonic indentation in the central Alboran Sea

\section{Abstract}

The Alboran Sea constitutes a Neogene-Quaternary basin of the Betic-Rif Cordillera, which has been deformed since the Late Miocene during the collision between the Eurasian and African plates in the westernmost Mediterranean. NNE-SSW sinistral and WNW-ESE dextral conjugate fault sets forming a $75^{\circ}$ angle surround a rigid basement spur of the African plate, and are the origin of most of the shallow seismicity of the central Alboran Sea. Northward, the faults decrease their

This article has been accepted for publication and undergone full peer review but has not been through the copyediting, typesetting, pagination and proofreading process, which may lead to differences between this version and the Version of Record. Please cite this article as doi: $10.1111 /$ ter.12304

This article is protected by copyright. All rights reserved. 
transcurrent slip, becoming normal close to the tip point, while NNW-SSE normal and sparse ENEWSW reverse to transcurrent faults are developed. The uplifting of the Alboran Ridge ENE-WSW antiform above a detachment level was favoured by the crustal layering. Despite the recent anticlockwise rotation of the Eurasian-African convergence trend in the westernmost Mediterranean, these recent deformations - consistent with indenter tectonics characterized by a $\mathrm{N} 164^{\circ} \mathrm{E}$ trend of maximum compression - entail the highest seismic hazard of the Alboran Sea.

\section{Introduction}

The style of deformation during plate convergence relating to the building of mountain belts is a consequence of the rheological behaviour of the convergent lithospheres (Pysklywec et al., 2002; Willett et al., 2003; Moore et al., 2005). A similar buoyancy of continental crusts in collisional orogens, combined with the rigid rheological behaviour of colliding tectonic elements, favours indenter tectonics (Cobbold and Davy, 1988; Davy and Cobbold, 1988) related to escape tectonics (Jacobs and Thomas, 2004). Analogue modelling suggests that conjugate sets of transcurrent faults occur when confinement decreases (Tapponier et al., 1982; Davy and Cobbold, 1988). Conjugate fault sets generally form at a higher angle during indenter tectonics than in the classical Anderson model ( $\sim 0^{\circ}$; Anderson, 1942), and end suddenly, far away from the deformation front (Tapponier et al., 1982). Many studies have focused on the Himalayas as the most relevant example of evolved collision in which the presence of rigid crustal blocks led to great heterogeneities in the indentertectonic deformation pattern (Molnar and Tapponier, 1975; Coward et al., 1986). The initial stages of collisional processes are poorly known, being mainly analysed in emerged orogenic belts such as the Caucasus (Philip et al., 1989) and New Zealand (Pysklywec et al., 2002).

The Alboran Sea (westernmost Mediterranean) constitutes a natural example of the initial stage of continental collision between the Eurasian and African plates (Carminati et al., 2012). It is a Neogene basin surrounded by the Betic-Rif Cordillera that makes up the Arc of Gibraltar (Fig. 1) (Comas et al., 1992). During the Early Miocene, continental crustal thinning occurred (Vissers et al., 
1995), followed by a compressive period since the Late Tortonian (Sanz de Galdeano and Alfaro, 2004). Tectonic models for the recent evolution of the area support subduction activity (Doglioni et al., 1997, 1999; Morales et al., 1999; Gutscher et al., 2002; Ruiz-Constán et al., 2011) and possible roll-back processes (Zeck, 1999; González-Castillo et al., 2015; do Couto et al., 2016) or delamination (Docherty and Banda, 1995; Seber et al., 1996; de Lis Mancilla et al., 2013). All the models hold that the internal zones of the Betic-Rif Cordillera move westward above the Africa-Eurasia plate boundary (Koulali et al., 2011; Palano et al., 2015). Recent and active deformation has a heterogeneous distribution, thereby favouring indenter and escape tectonics (Chalouan et al., 2006; Chabli et al., 2014). An anticlockwise rotation of the Eurasian-Nubian (West African or former African) plate convergence trend (Calais et al., 2003; DeMets et al., 2015) presently determines a $\mathrm{N} 141^{\circ} \mathrm{E}$ trend of convergence at a rate of $4.93 \mathrm{~mm} / \mathrm{yr}$ in the western Mediterranean (GEODVEL models, Argus et al., 2010), which is roughly supported by GPS data (Fadil et al., 2006; Nocquet, 2012). The region is affected by widespread seismicity (Buforn et al., 1995) taking place in an E-W broad deformation band over $300 \mathrm{~km}$ wide. Fadil et al. (2006) revealed the importance of the NESW Al Idrissi fault zone with intense seismicity in the southern Alboran Sea.

The Alboran Sea is floored by thin asymmetric continental crust above an anomalous mantle (Bonini, 1973). The crust reaches about $15 \mathrm{~km}$ northward, near the boundary with the Betic Cordillera, and increases southward, to the African margin (Suriñach and Vegas, 1993; Soto et al., 2008; Petit et al., 2015). The crustal structure consists of a metamorphic basement comprising Alpine (Aparicio et al., 1991; Platt et al., 1996) and Variscan tectonic units that are thrusted in the Betics (Galindo-Zaldívar et al., 1997). The Neogene cover includes sedimentary rocks deposited since the Early Miocene along with basic and intermediate volcanic rocks of Tortonian age (Duggen et al., 2004). Large magnetic anomaly dipoles are related to ENE-WSW-elongated basic rock bodies (Galindo-Zaldívar et al., 1998); the largest one roughly constitutes the basement of the Alboran Channel (Fig. 2). This active tectonic region is deformed by inherited and new faults (e.g., Serrata- 
Carboneras, Yusuf and Al Idrissi faults) and folds (e.g., Alboran Ridge) (Ammar et al., 2007; MartínezGarcía et al., 2010) (Fig. 1) that determine the bathymetric features (Ballesteros et al., 2008; Lafosse et al., 2016). These structures extend northward to the Campo de Dalias, and are deformed by ENEWSW-oriented folds (Fig. 2); conjugated hybrid and tensional fractures support ENE-WSW extension and orthogonal NNW-SSE compression (Marín-Lechado et al., 2005; Pedrera et al., 2015). Southwards, deformation extends towards the Rif through the region of Al Hoceima, which is affected by normal and strike-slip faults (Galindo-Zaldívar et al., 2009, 2015; d'Acremont et al., 2014; Poujol et al., 2014; van der Woerd et al., 2014; Lafosse et al., 2016).

The collisional tectonic setting is highly relevant in the eastern (Robertson, 1988) and western Mediterranean (Ruiz-Constán et al., 2011; Carminati et al., 2012; Roure et al., 2012; Estrada et al., 2014); the Alboran Sea is the best region to analyse the main tectonic features developed in the initial stages, and is not yet studied in detail. The aim of this contribution is to analyse the recent and active tectonic deformation of the central Alboran Sea in the framework of recent relative plate motions. Mapping and study of the faults and folds, together with their distribution and relationship with the main crustal structures, allows us to propose a new model of indenter tectonics for the Eurasian-Nubia convergence in the Alboran Sea during the initial stage of continental collision.

\section{Main tectonic structures}

Multibeam bathymetry (Ercilla et al., 2016), masked by the GEBCO bathymetry in areas of poor coverage, and multi- and single-channel seismic profiles with different degrees of resolution reveal that both faults and folds have been deforming the Central Alboran Sea since the Miocene (Figs. 2-6). Regional seismicity and morphological features suggest that most of these structures are active (Fig. 2a,e).

Faults are distributed in two main well-defined $\mathrm{N} 25^{\circ} \mathrm{E}$ sinistral and $\mathrm{N} 130^{\circ} \mathrm{E}$ dextral conjugate sets that form an angle of $75^{\circ}$ (Fig. $2 \mathrm{a}, \mathrm{C}$ ). The strike-slip character is inferred from the roughly 
vertical fault dip (Figs. 3-5), the displacement of morphological features, mainly in the Alboran Channel boundaries (Fig. 2a), and earthquake focal mechanisms resembling those of the nearby Al Idrissi fault zone (Martínez-García et al., 2013; d'Acremont et al., 2014). Faults with a normal component and intermediate $\mathrm{N} 130^{\circ} \mathrm{E}$ to $\mathrm{N} 170^{\circ} \mathrm{E}$ strikes are also recognized, dipping northeastward and southwestward and mostly affecting recent sediments or even reaching the surface (Figs. 3 and 4). ENE-WSW faults constitute the main structures in the Serrata-Carboneras fault (Gracia et al., 2006) and Alboran Ridge; however, they are scarcely represented in the central fault system (Fig. 2a).

The distribution of the fault sets reflects two main fault zones surrounding the South Alboran basement rigid spur attached to the African margin (Fig. 2a). The NNE-SSW sinistral fault zone, including the Al-Idrissi fault, reaches lengths of up to $38 \mathrm{~km}$. Meanwhile, the eastern boundary is formed by the NW-SE dextral set, with the Yusuf Fault zone (120 km in length) and other faults reaching $40 \mathrm{~km}$ in length. The Alboran Ridge mainly corresponds to an ENE-WSW-elongated southward-vergent antiform (Fig. 6) over $120 \mathrm{~km}$ long that crosses the northern part of the basement spur and divides the Alboran Sea into the Eastern and Western Alboran basins; it is affected by the Al Idrissi fault, which causes a short sinistral displacement with respect to the Frances Pages Bank (Fig. 2a). In the Alboran Channel and Northern Alboran Sea, these two fault sets exhibit cross-cut relationships supporting their simultaneous development, and their geometry is roughly symmetrical in the central part (Fig. 2a). The NW-SE Averroes Fault (Figs. 2a and 5) is considered representative of the behaviour of most of these structures. Its strike-slip component, well marked by the displacement of the northern slopes of the Alboran Channel, decreases northward until the fault becomes normal towards the tip line. Found to the north are a $\mathrm{N} 130^{\circ}$ to $\mathrm{N} 170^{\circ}$ set of short normal faults with both eastward and westward dips; these faults affect the coast near El Campo de Dalías (Fig. 2a), where the presence of ENE-WSW folds with progressive activity since the Late Miocene is also evidenced by seismic profiles and field observations (Pedrera et al., 
2015). Finally, the trace of the Serrata-Carboneras Fault is further evidenced by the bathymetry (Fig. 2a), although no recent activity can be demonstrated.

\section{Discussion and conclusions}

Deformation related to the Eurasian-African plate boundary has a heterogeneous distribution in the westernmost Mediterranean. Recent and active faults and folds are concentrated along the northern boundaries of a relatively low deformed area located in the South Alboran Basin (Figs. 2a, 7) with scarce seismicity (Fig. 2e). Northwards, the presence of inherited ENE-WSW rigid elongated basic rocks in the Alboran Channel (Figs. 2b, 7) and the easily deformable thin continental crust facilitated the development of the Alboran Ridge antiform. The area is bounded northwestward by the Al Idrissi fault zone, which reaches the African margin (Lafosse et al., 2016) with related seismicity, and northeastward by the Yusuf fault, with scarce to moderate activity (Fig. 2). This low deformed area may be interpreted as a basement spur attached to the African margin, and its boundaries constitute main heterogeneities (Fig. 7). The deformation propagated from the basement spur towards the northern Alboran Sea, extending up to the Campo de Dalías (Figs. 2a, 7). The two sets of conjugate wrench faults - the WNW-ESE dextral fault zone including the Yusuf Fault and the NNE-SSW sinistral Al Idrissi fault zone (Figs. 2a,c,d and 7) - are distributed roughly symmetrically, in two fault zones that reflect the boundaries of the northward African margin basement spur. A scenario of indenter tectonics is supported by: i) the simultaneous development of the two sets of faults as determined from cross-cutting relationships (Fig. 2a); ii) the northward decrease of the fault slip, becoming normal in some cases before the tip point (such as the Averroes Fault, Fig. 5); and iii) the presence of short irregular NNW-SSE normal faults in the northern Alboran Sea (Fig. 2a). The fault system pattern evokes laterally unlocked boundary experiments, developing conjugate faults where the slip decreases, far from the indenter (Tapponier et al., 1982; Davy and Cobbold, 1988). This setting suggests that both the East and West Alboran basins could be free boundaries (Fig. 2a), involving a fault architecture different from the classical asymmetrical models

This article is protected by copyright. All rights reserved. 
of Himalaya collision that are unlocked on one side (Tapponier et al., 1982). Moreover, the $75^{\circ}$ conjugate fault angle (Fig. 2c,d) exceeds the typical $60^{\circ}$ of Anderson (1942) described in the context of indenter tectonics (Tapponier et al., 1982; Davy and Cobbold, 1988).

The formation of the ENE-WSW Alboran Ridge, an isolated antiform affecting the frontal part of the African margin, was most likely favoured by the development of detachments at relatively shallow levels during the collision of a mechanically layered crust (Fig. 7). The detachments would have separated the folded sedimentary and volcanic cover from the metamorphic basement. Basement shortening may be accommodated by deep ductile distributed deformation (Fig. 7b) or by local thrusting developing a pop-up structure (Fig. 7c), but there is no evidence of local subduction. The NE region, near Campo de Dalías, is also deformed by folds, suggesting the presence of similar detachment structures (Pedrera et al., 2015). Yet, in the Alboran Channel and northern Alboran Sea, the thin crust is intruded by igneous edifices, favouring the development of conjugate strike-slip faults. These sectors show how the behaviour of the continental crust differs, according to the intracrustal and basement-sedimentary-cover anisotropies. The indenter tectonics would therefore be responsible for the heterogeneous relief in the central Alboran Sea during the closure of the oceanic gateway, developing a main barrier separating the eastern and western Alboran Sea.

Palaeostress determination in view of the conjugate fault sets and folds, such as the large Alboran Ridge antiform, indicates a $\mathrm{N} 165^{\circ} \mathrm{E}$ compressional trend and orthogonal extension (Figs. 2 and 7). This contrasts with the present-day $\mathrm{N} 141^{\circ} \mathrm{E}$ trend predicted by the regional plate boundary Geodvel model based on GPS data (Argus et al., 2010), in agreement with recent determinations based on magnetic anomalies (DeMets et al., 2015). This apparent inconsistency may be a consequence of the inherited character of the main deep crustal faults, which formed in previous stress fields that later underwent anticlockwise rotation. Alternatively, this setting may have been

This article is protected by copyright. All rights reserved. 
produced by strain partitioning in the broad deformation zone of the plate boundary, where the Alboran Sea dominates the convergence.

In summary, the Central Alboran Sea - located in the westernmost Mediterranean between the Western Alboran and Algerian basins - is a region undergoing the initial stages of continental collision between Eurasian and African crusts of similar buoyancy, deformed by laterally unlocked indentation tectonics. Our tectonic model reveals for the first time a role for indentation tectonics in the Eurasian-Nubia plate collision. This model increases our understanding of the recent geodynamic evolution of the Alboran Sea, resulting from the inherited heterogeneities of the African margin, which include a rigid spur pushing a frontal rigid basement basic rock body that has indented into the easily deformable thinned continental crust of the northern Alboran Sea. The indenter structures would therefore be the main deformations accommodating Eurasian-African plate motion in the central Alboran Sea. The Al-Idrisi and Yusuf fault zones and the Alboran Ridge antiform constitute the northern boundary between the African plate and the deformation zone related to the plate boundary, thereby entailing the highest seismic hazard in the region. This tectonic model may have important implications for other Mediterranean regions; it also enhances our knowledge of the initial stages of continental collision in other geographic scenarios, past and present.

\section{Acknowledgements}

Prof. Corsini and two anonymous reviewers improved this contribution. Financed by FAUCES (CTM2015-65461-C2-1-R), DAMAGE (AEI/FEDER CGL2016-80687-R) and RNM148. IHS-Kingdom Suite educational license.

\section{References}

Ammar, A., Mauffret, A., Gorini, C. and Jabour, H., 2007. The tectonic structure of the Alboran Margin of Morocco. Revista de la Sociedad Geológica de España, 20, 247-271.

This article is protected by copyright. All rights reserved. 
Anderson, E. M., 1942. The Dynamics of Faulting 1st ed., 206, Olivier and Boyd, Edinburgh, 1942.

Aparicio, A., Mitjavila, J. M., Araña, V. and Villa, M., 1991. La edad del volcanismo de las islas Columbrete Grande y Alborán (Mediterraneo occidental). Bol. Geol. Miner., 102-104, 74-82.

Argus, D.F., Gordon, R. G., Heflin, M.B., Ma, C., Eanes, R. J., Willis, P., Peltier, W. R., and Owen, S. E., 2010. The angular velocities of the plates and the velocity of the Earth's centre from space geodesy. Geophys. J. Int., 18, 1-48.

Ballesteros, M., Rivera, J., Munoz, A., Munoz-Martin, A., Acosta, J., Carbó, A. and Uchupi, E., 2008. Alboran Basin, southern Spain--Part II: Neogene tectonic implications for the orogenic float model. Marine and Petroleum Geology, 25, 75-101.

Bonini, W. E., Loomis, T. P. and Robertson, J. D., 1973. Gravity anomalies, ultramafic intrusions, and the tectonics of the region around the Strait of Gibraltar. Journal of Geophysical Research, 78, 1372-1382.

Bonini, M., 2007. Deformation patterns and structural vergence in brittle-ductile thrust wedges: an additional analogue modelling perspective. Journal of Structural Geology, 29, 141-158.

Buforn, E., Sanz de Galdeano, C., and Udías, A., 1995. Seismotectonics of the Ibero-Maghrebian region. Tectonophysics, $\mathbf{2 4 8 ,}$ 247-261.

Calais, E., DeMets, C. and Nocquet, J.M., 2003. Evidence for a post-3.16-Ma change in Nubia-Eurasia-North America plate motions?. Earth and Planetary Science Letters, 216, 81-92.

Carminati, E., Lustrino, M., and Doglioni, C., 2012. Geodynamic evolution of the central and western Mediterranean: Tectonics vs. igneous petrology constraints. Tectonophysics, 579, 173-192.

Chabli, A., Chalouan, A., Akil, M., Galindo-Zaldívar, J., Ruano, P., Sanz de Galdeano, C., López-Garrido, A. C., Marín-Lechado, C. and Pedrera, A., 2014. Plio-Quaternary paleostresses in the Atlantic passive margin of the Moroccan Meseta: Influence of the Central Rif escape tectonics related to Eurasian-African plate convergence. Journal of Geodynamics, 77, 123-134.

Chalouan, A., Galindo-Zaldívar, J., Akil, V., Marín, C., Chabli, A., Ruano, P., Bargach, K., Sanz de Galdeano, C., Benmakhlouf, M., Ahmamou, M. and Gourari, L., 2006. Tectonic wedge escape in the southwestern front of the Rif Cordillera (Morocco). Geological Society, London, Special Publications 2006, 262, 101118.

Cobbold, P. R. and Davy, P. H., 1988. Indentation tectonics in nature and experiment. 2. Central Asia, Bull. Geol. Inst. Univ. Uppsala, 14, 143-162.

This article is protected by copyright. All rights reserved. 
Comas, M. C., García-Dueñas, V., and Jurado, M. J., 1992. Neogene tectonic evolution of the Alboran Sea from MCS data. Geo-Marine Letters, 12, 157-164.

Comas, M.C., Platt, J.P., Soto, J.I. and Watts, A.B., 1999. The Origin and Tectonic History of the Albora'n Basin: insights from Leg 161 Results. In: Proc. ODP, Sci. Results (Ed. by R. Zahn, M.C. Comas and A. Klaus), Ocean Drilling Program, College Station, TX, 161, 555-580.

Coward, M. P., Rex, D. C., Khan, M. A., Windley, B. F., Broughton, R. D., Luff, I. W., Petterson, M. G. and Pudsey, C. J., 1986. Collision tectonics in the NW Himalayas. Geological Society, London, Special Publications, 19, 203-219.

d'Acremont, E., Gutscher, M. A., Rabaute, A., de Lépinay, B. M., Lafosse, M., Poort, J., Ammar, A., Tahayt A., Le Roy, P., Smit, J., do Couto, D., Cancouët, R., Prunier, C., Ercilla, G. and Gorini, C., 2014. High-resolution imagery of active faulting offshore Al Hoceima, Northern Morocco. Tectonophysics, 632, 160-166.

Davy, P. and Cobbold, P. R. (1988). Indentation tectonics in nature and experiment. 1. Experiments scaled for gravity. Bull. Geol. Inst. Univ. Uppsala, 14, 129-141.

de Lis Mancilla, F., Stich, D., Berrocoso, M., Martín, R., Morales, J., Fernandez-Ros, A., Páez, R. and Pérez-Peña, A., 2013. Delamination in the Betic Range: Deep structure, seismicity, and GPS motion. Geology, 41, 307-310.

DeMets, C., laffaldano, G. and Merkouriev, S., 2015. High-resolution Neogene and Quaternary estimates of Nubia-Eurasia-North America Plate motion. Geophys. J. Int., 203, 416-427.

Docherty, C. and Banda, E., 1995. Evidence for the eastward migration of the Alboran Sea based on regional subsidence analysis: a case for basin formation by delamination of the subcrustal lithosphere?. Tectonics, 14, 804-818.

Do Couto, D., Gorini, C., Jolivet, L., Lebret, N., Augier, R., Gumiaux, C., d'Acremont, E., Ammar, A., Jabour, H. and Auxietre, J. L., 2016. Tectonic and stratigraphic evolution of the Western Alboran Sea Basin in the last 25 Myrs. Tectonophysics, 677-678, 280-311.

Doglioni, C., Gueguen, E., Sabat, F. and Fernandez, M., 1997. The western Mediterranean extensional basins and the Alpine orogen. Terra Nova, 9, 109-112.

Doglioni, C., Gueguen, E., Harabaglia, P. and Mongelli, F., 1999. On the origin of W-directed subduction zones and applications to the western Mediterranean. Geol. Soc. Spec. Publ., 156, 541-561.

This article is protected by copyright. All rights reserved. 
Duggen, S., Hoernle, K., van den Bogaard, P. and Harris, C., 2004. Magmatic evolution of the Alboran region: The role of subduction in forming the western Mediterranean and causing the Messinian Salinity Crisis. Earth and Planetary Science Letters, 218, 91-108.

Ercilla, G., Juan, C., Hernández-Molina, F.J., Bruno, M., Estrada, F., Alonso, B., Casas, D., Farran, M., Llave, E., García, M., Vázquez, J.T., d'Acremont, E., Gorini, C., Palomino, D., Valencia, J., El Moumni, B. and Ammar, A., 2016. Significance of bottom currents in deep-sea morphodynamics: An example from the Alboran Sea. Marine Geology, 378, 157-170.

Estrada F., Vázquez J.T., Ercilla G., Alonso B., d’Acremont E., Gorini C., Gómez M., Fernández-Puga M.C., Ammar A. and El Moumni B., 2014. Inversión tectónica reciente de la zona central de Alborán. In “Una aproximación multidisciplinar al estudio de las fallas activas, los terremotos y el riesgo sísmico", (J. A. Álvarez-Gómez and F. Martín González, eds.). Segunda reunión ibérica sobre fallas activas y paleosismología, Lorca, Spain, 93-96.

Fadil, A., Vernant, P., McClusky, S., Reilinger, R., Gomez, F., Ben Sari, D., Mourabit, T., Feigl, K. and Barazangi, M., 2006. Active tectonics of the western Mediterranean: geodetic evidence for rollback of a delaminated subcontinental lithospheric slab beneath the Rif Mountains, Morocco. Geology, 34, 529532.

Galindo-Zaldivar, J., Jabaloy, A., Gonzalez-Lodeiro, F. and Aldaya, F. 1997. Crustal structure of the central sector of the Betic Cordillera (SE Spain). Tectonics, 16, 18-37.

Galindo-Zaldivar, J., Gonzalez-Lodeiro, F., Jabaloy, A., Maldonado, A., and Schreider, A. A., 1998. Models of magnetic and Bouguer gravity anomalies for the deep structure of the central Alboran Sea basin. GeoMarine Letters, 18, 10-18.

Galindo-Zaldívar, J., Maldonado, A. and Schreider, A. A., 2003. Gorringe Ridge gravity and magnetic anomalies are compatible with thrusting at a crustal scale. Geophysical Journal International, 153, 586-594.

Galindo-Zaldívar, J., Chalouan, A., Azzouz, O., Sanz De Galdeano, C., Anahnah, F., Ameza, L., Ruano, P., Pedrera, A., Ruiz-Constán, A., Marín-Lechado, C., Benmakhlouf, M., López-Garrido, A. C., Ahmamou, M., Saji, R., Roldán-García, F. J., Akil, M. and Chabli, A., 2009. Are the seismological and geological observations of the Al Hoceima (Morocco, Rif) 2004 earthquake (M=6.3) contradictory?. Tectonophysics, 475, 59-67.

Galindo-Zaldívar, J., Azzouz, O., Chalouan, A., Pedrera, A., Ruano, P., Ruiz-Constán, A., Sanz de Galdeano, C., Marín-Lechado, C., López-Garrido, A. C., Anahnah, F. and Benmakhlouf, M., 2015. Extensional tectonics,

This article is protected by copyright. All rights reserved. 
graben development and fault terminations in the eastern Rif (Bokoya-Ras Afraou area). Tectonophysics, 663, 140-149.

Gonzalez-Castillo, L., Galindo-Zaldivar, J., de Lacy, M. C., Borque, M. J., Martinez-Moreno, F. J., GarcíaArmenteros, J. A., and Gil, A. J., 2015. Active rollback in the Gibraltar Arc: Evidences from CGPS data in the western Betic Cordillera. Tectonophysics, 663, 310-321.

Gràcia, E., Pallàs, R., Soto, J.I., Comas, M., Moreno, X., Massana, E., Santanach, P., Díez, S., García, M. and Dañobeitia, J., 2006. Active faulting offshore SE Spain (Alboran Sea): implications for earthquake hazard assessment in the Southern Iberian Margin. Earth Planet. Sci. Lett., 241, 734-749.

Gutscher, M. A., Malod, J., Rehault, J. P., Contrucci, I., Klingelhoefer, F., Mendes-Victor, L. and Spakman, W., 2002. Evidence for active subduction beneath Gibraltar. Geology, 30, 1071-1074.

Huiqi, L., McClay, K. R. and Powell, D., 1992. Physical models of thrust wedges. In Thrust tectonics (pp. 71-81). Springer, The Netherlands.

Jacobs, J. and Thomas, R. J., 2004. Himalayan-type indenter-escape tectonics model for the southern part of the late Neoproterozoic-early Paleozoic East African- Antarctic orogeny. Geology, 32, 721-724.

Koulali, A., Ouazar, D., Tahayt, A., King, R. W., Vernant, P., Reilinger, R. E., McClusky, S., Mourabit, T., Davila, J. M. and Amraoui, N., 2011. New GPS constraints on active deformation along the Africa-lberia plate boundary. Earth and Planetary Science Letters, 308, 211-217.

Lafosse, M., d’ Acremont E., Rabaute A., Mercier de Lépinay B., Tahayt A., Ammar A. and Gorini C., 2016. Imagery of recent offshore tectonic Quaternary structures of the Nekor basin (Morocco): evidence of an offshore/ onshore transtensive basin. Tectonophysics, 632, 160-166.

Maestro-González, A., Bárcenas, P, Vázquez, J. T. and Díaz-del-Río V., 2008. The role of basement inheritance faults in the recent fracture system of the inner shelf around Alboran Island, Western Mediterranean. Geo-Marine Letters, 28, 53-64.

Maldonado, A., Campillo, A. C., Mauffret, A., Alonso, B., Woodside, J. M. and Campos, J., 1992. Alboran Sea Late Cenozoic tectonic and stratigraphic evolution. Geo-Marine Letters, 12, 179-186.

Marín-Lechado, C., Galindo-Zaldívar, J., Rodríguez-Fernández, L. R., Serrano, I. and Pedrera, A., 2005. Active faults, seismicity and stresses in an internal boundary of a tectonic arc (Campo de Dalías and Níjar, southeastern Betic Cordilleras, Spain). Tectonophysics, 396, 81-96.

This article is protected by copyright. All rights reserved. 
Martínez-García, P., Soto, J. I. and Comas, M., 2010. Structural analysis and recent tectonics in the central Alboran Sea. Trabajos de Geología, Universidad de Oviedo, 30, 44-48.

Martınez-Garcia, P., Comas, M., Soto, J. I., Lonergan, L. and Watts, A. B., 2013. Strike-slip tectonics and basin inversion in the Western Mediterranean: the Post-Messinian evolution of the Alboran Sea. Basin Research, 25, 1-27.

Molnar, P. and Tapponnier, P., 1975. Cenozoic tectonics of Asia: effects of a continental collision. Science, 189, 419-426.

Moore, V. M., Vendeville, B. C. and Wiltschko, D. V., 2005. Effects of buoyancy and mechanical layering on collisional deformation of continental lithosphere: Results from physical modeling. Tectonophysics, 403, 193-222.

Morales, J., Serrano, I., Jabaloy, A., Galindo-Zaldivar, J., Zhao, D., Torcal, F., Vidal, F. and Gonzalez-Lodeiro, F., 1999. Active continental subduction beneath the Betic Cordillera and the Alboran Sea. Geology, 27, 735-738.

Nocquet, J. M., 2012. Present-day kinematics of the Mediterranean: A comprehensive overview of GPS results. Tectonophysics, 579, 220-242.

Palano, M., González, P. J. and Fernández, J., 2015. The Diffuse Plate boundary of Nubia and Iberia in the Western Mediterranean: Crustal deformation evidence for viscous coupling and fragmented lithosphere. Earth and Planetary Science Letters, 430, 439-447.

Pedrera, A., Marín-Lechado, C., Galindo-Zaldívar, J. and Lobo, F. J. 2015. Smooth folds favoring gypsum precipitation in the Messinian Poniente marginal basin (Western Mediterranean). Tectonophysics, 663, 48-61.

Petit, C., Le Pourhiet, L., Scalabrino, B., Corsini, M., Bonnin, M. and Romagny, A.. 2015. Crustal structure and gravity anomalies beneath the Rif, northern Morocco: implications for the current tectonics of the Alboran region. Geophys. J. Int, 202, 640-652.

Philip, H., Cisternas, A., Gvishiani, A., and Gorshkov, A., 1989. The Caucasus: an actual example of the initial stages of continental collision. Tectonophysics, 161, 1-21.

This article is protected by copyright. All rights reserved. 
Platt, J. P., Soto, J. I. and Comas, M. C., 1996. Decompression and high-temperature-low-pressure metamorphism in the exhumed floor of an extensional basin, Alboran Sea, western Mediterranean. Geology, 24, 447-450.

Poujol, A., Ritz, J.F., Tahayt, A., Vernant, P., Condomines, M., Blard, P.H., Billant, J., Vacher, L., Tibari, B., Hni, L. and Idrissi, A.K., 2014. Active tectonics of the Northern Rif (Morocco) from geomorphic and geochronological data. Journal of Geodynamics, 77, 70-88.

Pysklywec, R. N., Beaumont, C. and Fullsack, P., 2002. Lithospheric deformation during the early stages of continental collision: Numerical experiments and comparison with South Island, New Zealand. Journal of Geophysical Research: Solid Earth, 107 (B7).

Robertson, A. H., 1998. Tectonic significance of the Eratosthenes Seamount: a continental fragment in the process of collision with a subduction zone in the eastern Mediterranean (Ocean Drilling Program Leg 160). Tectonophysics, 298, 63-82.

Roure, F., Casero, P. and Addoum, B., 2012. Alpine inversion of the North African margin and delamination of its continental lithosphere. Tectonics, 31 (3).

Ruiz-Constán, A., Galindo-Zaldívar, J., Pedrera, A., Celerier, B. and Marín-Lechado, C., 2011. Stress distribution at the transition from subduction to continental collision (northwestern and central Betic Cordillera). Geochemistry, Geophysics, Geosystems, 12.

Sanz de Galdeano, C. and Alfaro, P., 2004. Tectonic significance of the present relief of the Betic Cordillera. Geomorphology, 63, 175-190.

Seber, D., Barazangi, M., Ibenbrahim, A. and Demnati, A., 1996. Geophysical evidence for lithospheric delamination beneath the Alboran Sea and Rif-Betic mountains. Nature, 379, 785-790.

Soto, J. I., Fernández-Ibáñez, F., Fernández, M. and García-Casco, A., 2008. Thermal structure of the crust in the Gibraltar Arc: Influence on active tectonics in the western Mediterranean. Geochem. Geophys. Geosyst., 9 (10).

Suriñach, E. and Vegas, R., 1993. Estructura general de la corteza en una transversal del Mar de Alborán a partir de datos de sísmica de refracción-reflexión de gran ángulo. Interpretación geodinámica. Geogaceta, 14, 126-128.

Tapponier, P., Peltzer, A., Le Dain, Y. and Armijo, R., 1982. Propagating extrusion tectonics in Asia: new insights from simple experiments with plasticine. Geology, 10, 611-616.

This article is protected by copyright. All rights reserved. 
Torné, M., Fernandez, M., Comas, M. C. and Soto J. I., 2000. Lithospheric Structure Beneath the A!boran Basin: Results from 3D Gravity Modeling and Tectonic Relevance. Journal of Geophysical Research, 105, 32093228.

van der Woerd, J., Dorbath, C., Ousadou, F., Dorbath, L., Delouis, B., Jacques, E., Tapponnier, P., Hahou, Y., Menzhi, M., Frogneux, M. and Haessler, H., 2014. The Al Hoceima Mw 6.4 earthquake of 24 February 2004 and its aftershocks sequence. Journal of Geodynamics, 77, 89-109.

Vazquez, J.T., Alonso, B., Fernandez-Puga, M.C., Gomez-Ballesteros, M., Iglesias, J., Palomino, D., Roque, C., Ercilla, G. and Diaz-Del-Rio, V., 2015. Seamounts along the Iberian continental margins. Boletin Geologico y Minero, 126, 483-514.

Vissers, R. L. M., Platt, J. P. and Wal, D., 1995. Late orogenic extension of the Betic Cordillera and the Alboran Domain: a lithospheric view. Tectonics, 14, 786-803.

Willett, S., Beaumont, C. and Fullsack, P., 1993. Mechanical model for the tectonics of doubly vergent compressional orogens. Geology, 21, 371-374.

Zeck, H. P., 1999. Alpine plate kinematics in the western Mediterranean: a westward-directed subduction regime followed by slab roll-back and slab detachment. Geological Society, London, Special Publications, 156, 109-120.

\section{FIGURE CAPTIONS}

Fig. 1. Regional setting of the Alboran Sea in the framework of the Eurasian-African plate boundary and the westernmost Mediterranean. (a) Plate boundaries in the Azores-Gibraltar area (modified from Galindo-Zaldivar et al., 2003). Dots indicate areas of distributed deformation. BC, Betic Cordillera. GF, Gloria Fault. GR, Gorringe Ridge. GS, Gibraltar Strait. RC, Rif Cordillera. Contour lines in km; (b) Geological sketch of the main structural features and basins of the Alboran Sea (modified from Comas et al., 1999). AR, Alboran Ridge. AC, Alboran Channel. AdR, Adra Ridge. DB, Djibouti Bank. EAB, East Alboran Basin. FPB, Francesc Pagès Bank. SAB, South Alboran Basin. S-CF, SerrataCarboneras Fault. WAB, Western Alboran Basin. XTB, Xauen-Tofiño Bank. YF, Yusuf Fault. Black arrows indicate present-day direction of shortening.

This article is protected by copyright. All rights reserved. 
Fig. 2. Main tectonic features of the central Alboran Basin. (a) Detailed tectonic map. AC, Alboran Channel. AdR, Adra Ridge. ALF, Al-Idrisi Fault. AR, Alboran Ridge. CD, Campo de Dalías. DB, Djibouti Bank. FPB, Francesc Pagès Bank. S-CF, Serrata-Carboneras Fault. YF, Yusuf Fault. WAB, Western Alboran Basin. EAB, Eastern Alboran Basin. SAB, Southern Alboran Basin. (b) Magnetic anomaly map (nT) and bathymetric contours. Note the dipole bounding the northern side of the Alboran Ridge. (c) Fault set orientation. Blue arrows indicate palaeo-plate convergence and black arrows indicate present-day convergence. (d) General structural sketch. (e) Map of main tectonic structures and seismicity locations since 2000 .

Fig. 3. Seismic profiles showing NNE-SSW subvertical strike-slip faults in the central Alboran Basin. (a) Strike-slip faults with secondary normal components located in the volcanic edifice of Djibouti Bank. (b) Same faults as in (a) at the westernmost end of the Alboran Channel. Black line represents the base of the Pliocene; dashed line represents the base of the Quaternary. Scale: vertical in seconds (two-way travel time) and horizontal in km. Location in Fig. 2.

Fig. 4. Parametric TOPAS profiles showing conjugated subvertical faults affecting the seafloor of the central Alboran Basin (penetration about 60m). (a) Strike-slip faults north of Adra Ridge. (b) Normal faults at the northern end of the conjugated fault system. Scale: vertical in seconds (two way travel time) and horizontal in km. Location in Fig. 2.

Fig. 5. Seismic profiles showing the Averroes strike-slip fault in the central zone of the Alboran Basin.

(a) The northern end is characterized by a remarkable normal component, while the southern reach (b) displays a right lateral component. (c) Tectonic sketch of the Averroes fault and profile location (note the $164^{\circ} \mathrm{N}$ palaeostress vector); positive and negative signs represent uplifted and sunken areas respectively. Black line represents the base of the Pliocene; dashed line represents the base of 
the Quaternary. Scale: vertical in seconds (two-way travel time) and horizontal in km. Location in Fig. 2.

Fig. 6. Seismic profiles showing the geological structure across the central zone of the Alboran Basin. The Alboran Ridge antiform deforms Miocene deposits and tilts the Plio-Quaternary cover. (a) Eastern Alboran Ridge. (b) Western Alboran Ridge. AR, Alboran Ridge; AC, Alboran Channel; AdR, Adra Ridge. Black line represents the base of the Pliocene; dashed line represents the base of the Quaternary. Scale: vertical in seconds (two-way travel time) and horizontal in km. Location in Fig. 2.

Fig. 7. Sketch of indenter tectonic deformation of the central Alboran Sea. The model takes into account previous models based on deep crustal structures (Galindo-Zaldívar et al., 1998; Soto et al., 2008) as well as detailed information available on the recent tectonics of the Alboran Sea (e.g. Comas et al., 1992; Maldonado et al., 1992; Ballesteros et al., 2008; Maestro et al., 2008; MartínezGarcía et al., 2013; d’Acremont et al., 2014; Estrada et al., 2015; Vázquez et al., 2015; Do Couto et al., 2016; Lafosse et al., 2016), integrating the results into a new database of Alboran Sea geophysical data. (a) Westward oblique view of the main structures of the Central Alboran Sea (not to scale). Two models of crustal shortening are proposed to explain the Alboran Ridge antiform: (b) a detached level resulting from crustal thickening by means of deep ductile deformation, and (c) crustal pop-up through reverse faults.

This article is protected by copyright. All rights reserved. 

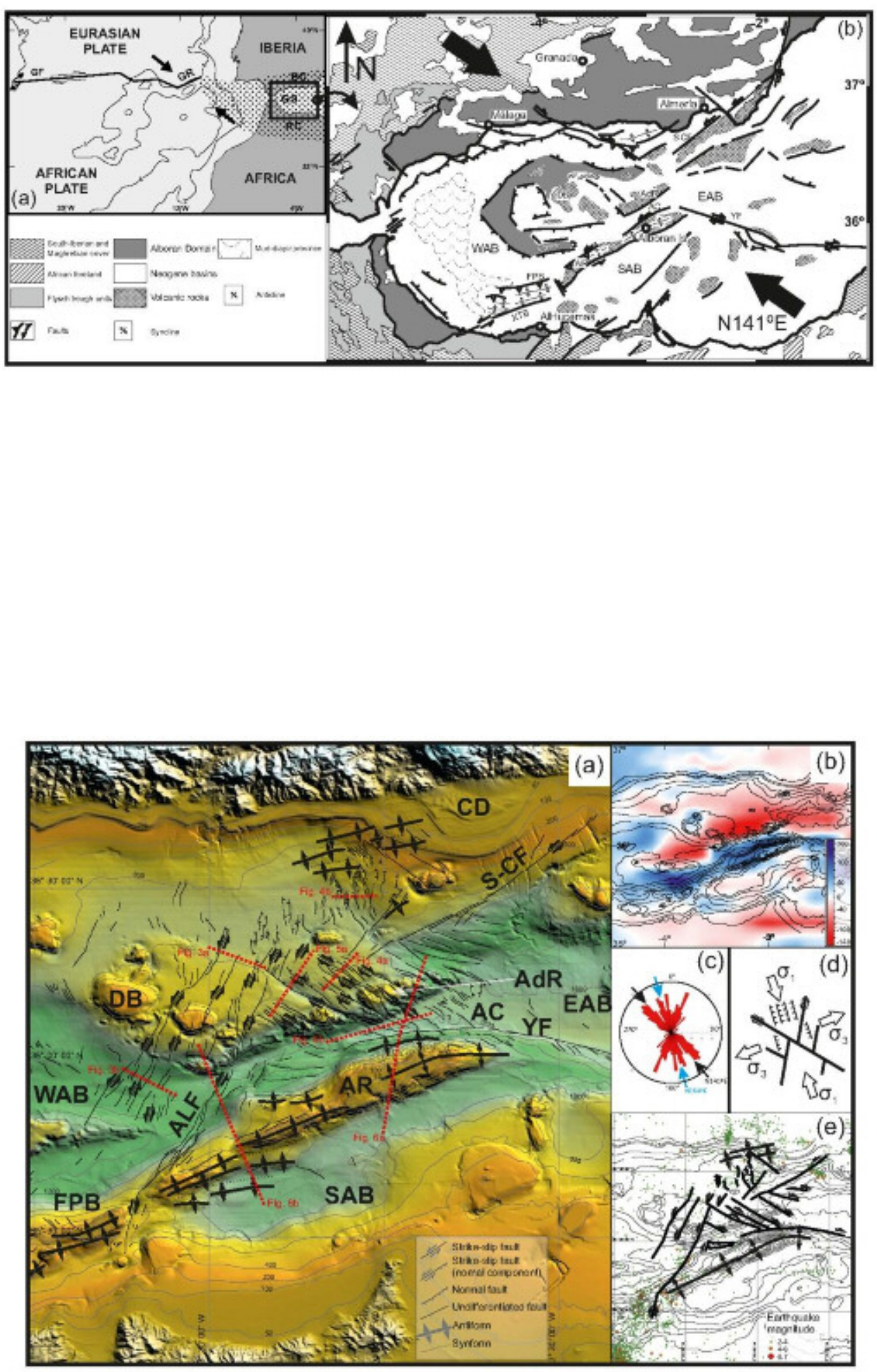

This article is protected by copyright. All rights reserved. 

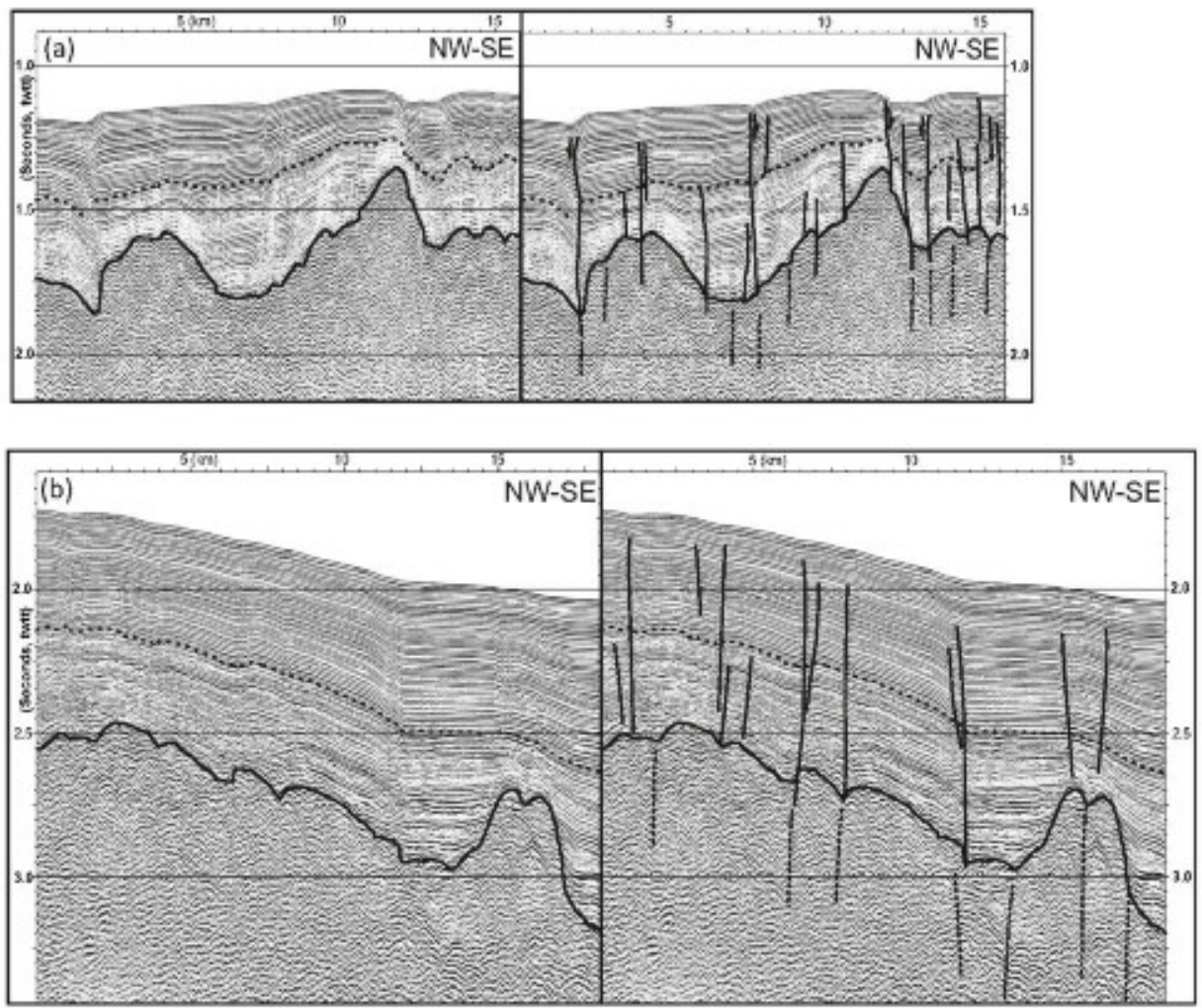

This article is protected by copyright. All rights reserved. 

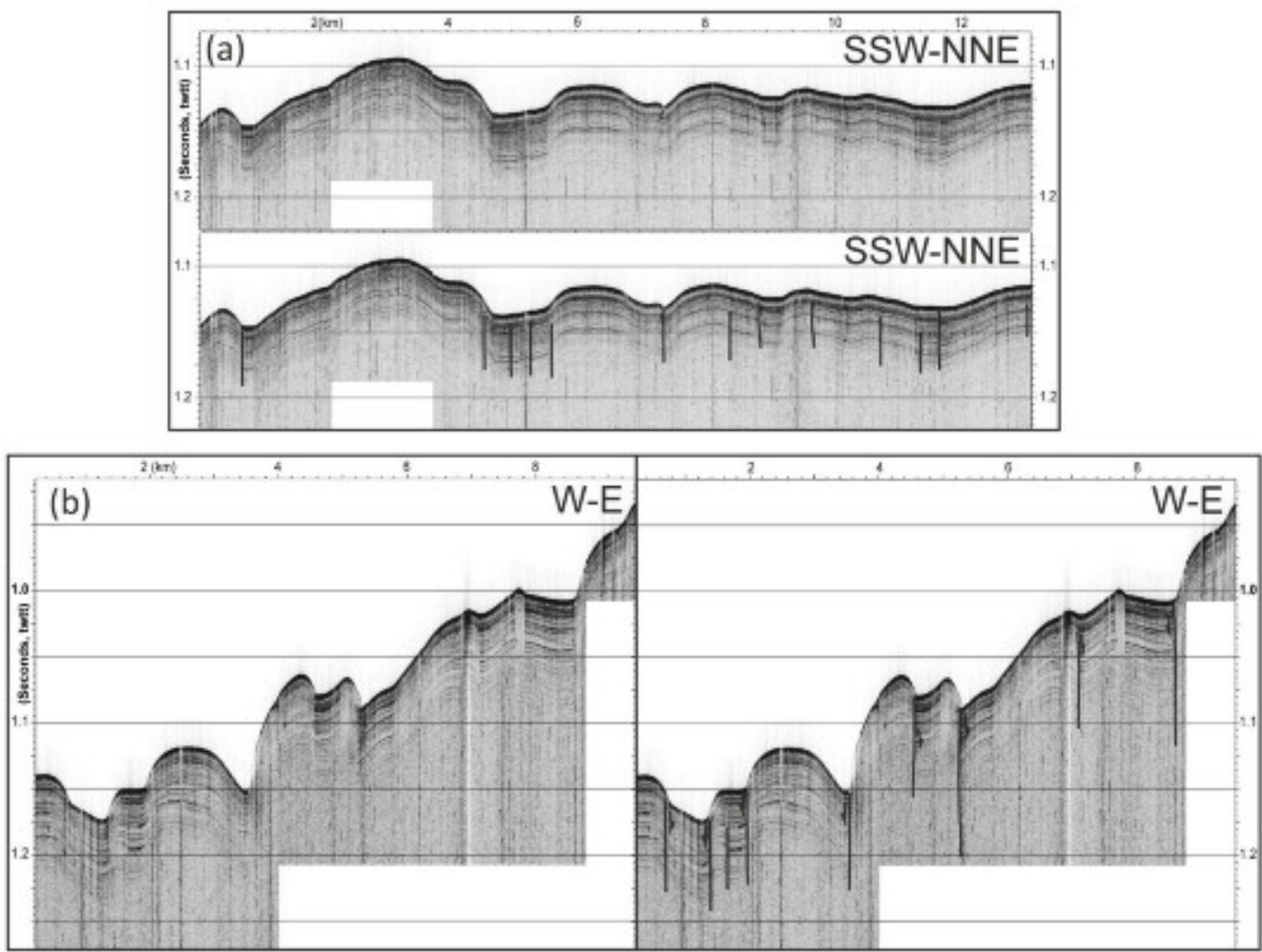

This article is protected by copyright. All rights reserved. 

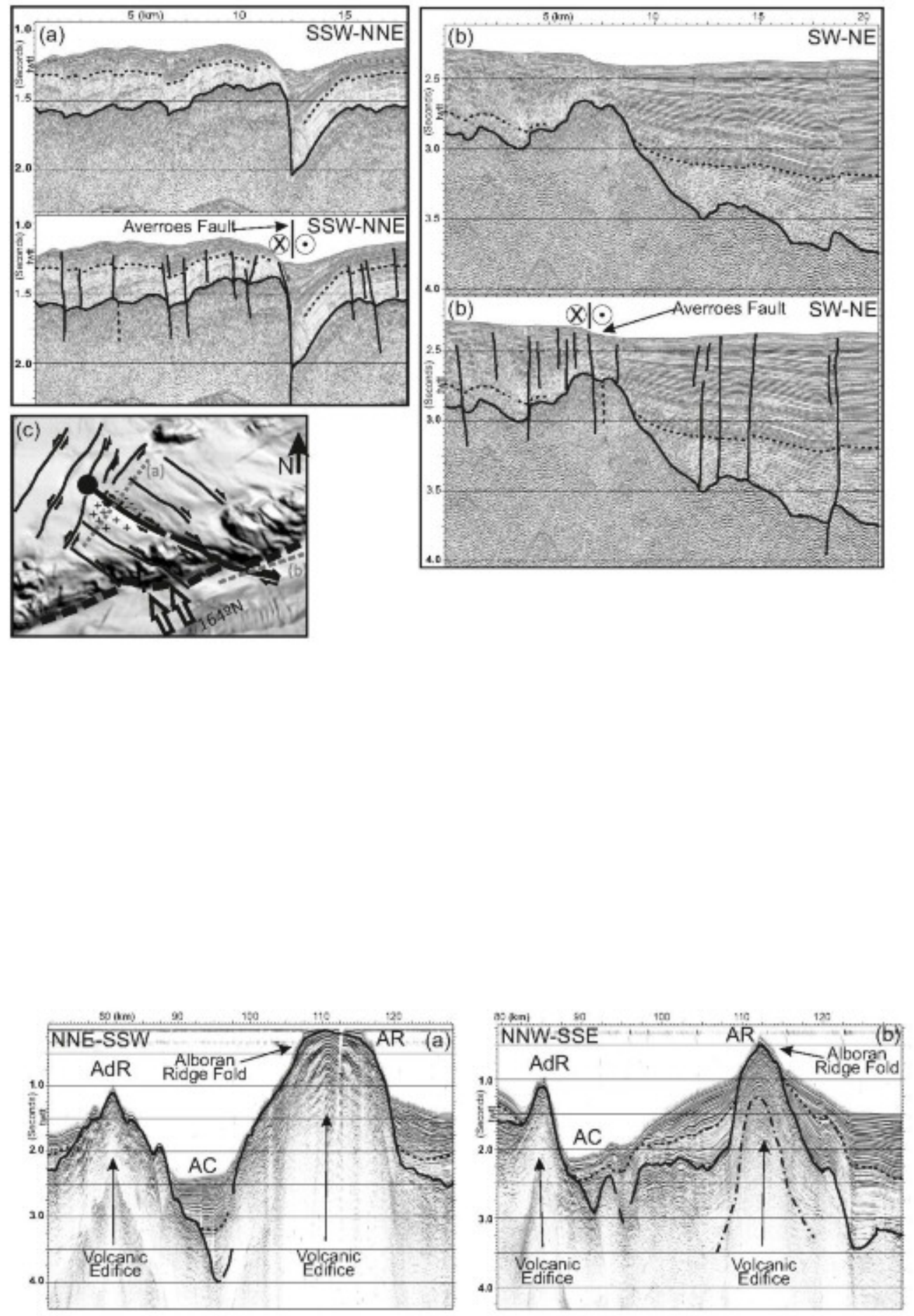

This article is protected by copyright. All rights reserved. 


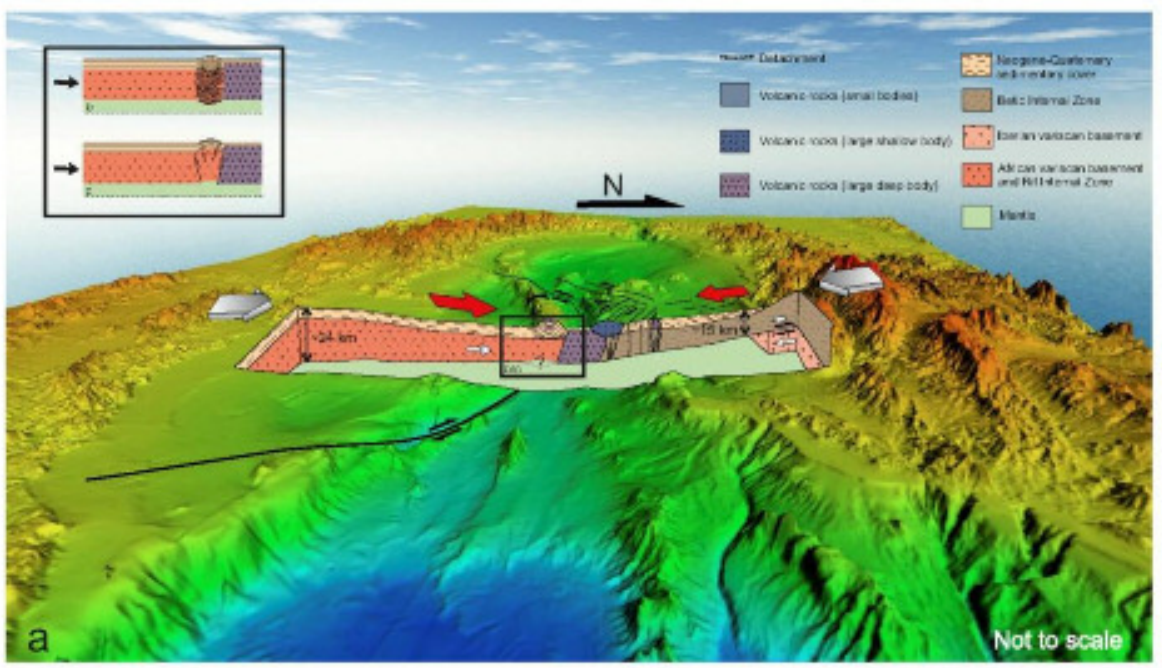

This article is protected by copyright. All rights reserved. 